\title{
Identification of a new DMD gene deletion by ectopic transcript analysis
}

Institut für

Humangenetik,

Gosslerstrasse 12d and

Abteilung

Kinderheilkunde:

Schwerpunkt

Neuropädiatrie,

Robert-Koch-Strasse

40, der

Universitätskliniken,

3400 Göttingen

Germany.

F Rininsland

A Hahn

S Niemann-Seyde

R Slomski

F Hanefeld

J Reiss

Correspondence to Dr Reiss, Institut für Humangenetik, Gosslerstrasse 12d, 3400 Göttingen, Germany.

Received 4 February 1992.

Revised version accepted 27 April 1992.

Frauke Rininsland, Andreas Hahn, Susanne Niemann-Seyde, Ryszard Slomski, Folker Hanefeld, Jochen Reiss

\begin{abstract}
The detailed genetic analysis of the Duchenne/Becker muscular dystrophy gene is hindered by the large number of exons involved and their separation by huge introns. These problems can be overcome by the analysis of $m R N A$ rather than genomic DNA and ectopic transcripts derived from peripheral blood lymphocytes provide a convenient source of material. Using reverse transcription and nested PCR, we show here a comprehensive strategy for the rapid and complete analysis of the coding sequences from complex genes and illustrate its potential by the identification of a hitherto undescribed single exon deletion. ( $\mathcal{F}$ Med Genet 1992;29:647-51)
\end{abstract}

Duchenne muscular dystrophy (DMD) is an $\mathrm{X}$ linked recessive disorder affecting approximately 1 in 3500 newborn males. ${ }^{1}$ In contrast to the mild allelic Becker muscular dystrophy (BMD), the Duchenne type is progressive and usually results in death during the second decade of life. The cDNA of the gene responsible for $\mathrm{DMD} / \mathrm{BMD}$ has been cloned ${ }^{2}$ and sequenced. ${ }^{3}$ The gene product has been named 'dystrophin' and is encoded by an mRNA of $14 \mathrm{~kb}$ derived from at least 74 exons spread over $2300 \mathrm{~kb}$ of the $\mathrm{X}$ chromosome. ${ }^{4}$

The extraordinary size of the gene causes extreme difficulties in molecular analysis. Although some $60 \%$ of DMD patients exhibit deletions, detection of these requires Southern blots and hybridisation with six different radiolabelled cDNA clones. ${ }^{5}$ Alternatively, $98 \%$ of the deletions may be detected after amplification of 19 different genomic fragments. ${ }^{6-8}$ Since both procedures are difficult to perform for quantitative evaluation, and since only $13 \%$ of deletions result in a readily detectable junction fragment, ${ }^{9}$ pulsed field gel electrophoresis is occasionally used for carrier detection in female relatives of Duchenne patients with deletions. This laborious procedure must also be applied to the detection of duplications, exhibited by another $6 \%$ of patients. ${ }^{10}$

The remaining one-third of patients are thought to carry mutations in promoter elements or point mutations and microdeletions either in the coding sequence or in splice site consensus sequences. Until recently, these mutations could not be detected, leaving the families to be counselled with rather unsatisfactory estimates of risk. Although a number of intragenic RFLPs are known and have been used for segregation analysis, ${ }^{11}$ indirect approaches are complicated by an intragenic recombination rate of up to $12 \%^{12}$ and the occurrence of new mutations in one-third of isolated cases. ${ }^{13}$ The use of flanking RFLP markers or the recently reported SSCP analysis of deleted regions ${ }^{14}$ might prove helpful in a fraction of cases, but are limited to informative allele constellations.

Bulman et $a l^{15}$ reported the first point mutation in the DMD gene. Western blot analysis of biopsied muscle material indicated a truncated protein. Subsequent cDNA sequence analysis in the implicated region of specifically expressed muscle transcripts showed a base substitution, creating a stop codon within exon 26. RNA analysis, in principle, should be much more straightforward for the analysis of the DMD gene since it reduces the size of the substrate to be studied to a coding region of approximately $11 \mathrm{~kb}$. Both procedures used by the above authors, however, required a muscle biopsy to obtain expressing tissue.

We and others have previously shown that 'ectopic' or 'illegitimate' transcription ${ }^{1617}$ in peripheral blood lymphocytes can be exploited to circumvent muscle biopsies for RNA studies and that pathological DMD/BMD transcripts resulting from a genomic deletion can be detected in both hemizygous patients and heterozygous carriers. ${ }^{1819}$ Roberts et al ${ }^{20}$ have already shown that this procedure can be used for a comprehensive analysis of the complete coding region without the use of radioactive substrates. However, all such studies to date were aimed at deletions already characterised at the genomic level. We report here a new DMD gene mutation, identified exclusively by means of ectopic lymphocyte cDNA analysis in a patient with no apparent deletion after extended multiplex DNA amplification.

\section{Case report}

The patient is of Polish origin. His early development was normal, and he was able to walk at 16 months. His family history was unremarkable. Progressive weakness, frequent falls, and the inability to climb stairs led to a clinical examination at the age of 4 years. He showed all the clinical symptoms of muscular dystrophy. His $\mathrm{CK}$ was raised to $13526 \mathrm{U} / 1$ (normal up to $50 \mathrm{U} / \mathrm{l}$ ). The muscle biopsy showed the typical dystrophic changes of DMD with negative staining for dystrophin using the two antibodies NCL-Dysl and NCL-Dys2 (Novocastra Laboratories). No genomic deletion was detected after multiplex amplification of 19 fragments, performed 
according to Chamberlain $e t a l^{67}$ and Beggs $e t$ $a l^{8}$ with minor modifications.

\section{Materials and methods}

RNA was isolated from peripheral blood lymphocytes and reverse transcribed as described elsewhere, ${ }^{18}$ using eight cDNA primers pooled in two sets of four 'odd' and four 'even' oligonucleotides ( $50 \mathrm{ng}$ each) in a total volume of $30 \mu \mathrm{l}$. A total of $7 \mu \mathrm{l}$ of the cDNA products was used for first round PCRs with eight oligonucleotide pairs spanning the whole coding region as overlapping fragments. Cycling conditions were: $30 \times$ one minute at $92^{\circ} \mathrm{C}, 45$ seconds at $53^{\circ} \mathrm{C}$, three minutes at $72^{\circ} \mathrm{C}$, final extension seven minutes, with $50 \mathrm{ng}$ of each oligonucleotide, $0.2 \mathrm{mmol} / 1 \mathrm{dNTPs}$, and 2.5 units TaqDNA-polymerase (Amersham, UK) in a total volume of $50 \mu \mathrm{l}$, according to the manufacturer's recommendation, in a thermocycler type 60 (Biomed, FRG).

Second round PCR was performed with $1 \mu l$ of the first round product and nested primers as described above. A total of $5 \mu \mathrm{l}$ of second round PCR products was electrophoresed in $1.2 \%$ agarose and visualised by ethidium bromide staining. Direct sequencing of PCR products was performed according to Zielenski et $a l^{21}$ All oligonucleotides were synthesised automatically (392 DNA/RNA synthesiser, Applied Biosystems, USA) and purified on Nensorb columns (DuPont, FRG). Sequences and usage of the different oligonucleotides are summarised in the table.

Genomic DNA was isolated by the method of Miller $e t a^{22}$ and amplified with $50 \mathrm{pmol}$ of primers $21 \mathrm{~F}$ (5'GATGAAGTCAACCGGCTATC, identical to the first bases of exon 21) and 21R (5'GTCTGTAGCTCTTTCTCTC, two nucleotides upstream of the $3^{\prime}$ end of exon 21 ) in 30 cycles (one minute at $92^{\circ} \mathrm{C}$, one minute at $48^{\circ} \mathrm{C}, 90$ seconds at $72^{\circ} \mathrm{C}$, final extension seven minutes at $72^{\circ} \mathrm{C}$ ) as described above using exon 55 as parallel control (55F: 5'GGCTGCTTTGGAAGAAACTC, 55R: 5'TTACGGGTAGCATCCTGTAGGA, 10 pmol each).

\section{Results}

Reverse transcription of peripheral blood lymphocyte RNA and two stage PCR amplification showed a truncated fragment in the DMD patient indicating the loss of approximately 200 bp between DMD gene exons 20 to 23 (fragment 3.2, fig 1). Direct sequencing of this fragment showed that exon 21 was absent in its entirety and that exon 20 was directly spliced to exon 22 (fig 2). Exon 21 is not included in routinely performed 'multiplex' genomic amplifications. Its absence, therefore, could have been caused either by a genomic deletion or by the mutation of a splice site junction leading to exon skipping. In order to distinguish between these two possibilities, exon 21

Sequences of the oligonucleotides used for $C D N A$ synthesis and PCR. The nomenclature refers to the cDNA sequence position (according to Koenig et al ${ }^{3}$ ) of the first nucleotide. Usage for cDNA synthesis and PCRs (see also fig 1) is indicated. Oligonucleotides homologous to the non-coding strand are marked $(R)$.

\begin{tabular}{|c|c|c|c|c|}
\hline \multicolumn{2}{|c|}{ Primer sequence $\left(5^{\prime}-3\right)$} & cDNA & $\frac{\text { 1st PCR }}{1}$ & $\begin{array}{c}\text { 2nd PCR } \\
1 \cdot 1 \\
1 \cdot 1 \\
1 \cdot 2 \\
1 \cdot 2\end{array}$ \\
\hline $\begin{array}{l}30 \\
996(R) \\
857 \\
1409(R) \\
1437 \\
1367 \\
1916(R) \\
1809 \\
2311(R) \\
2850 \\
2225 \\
2850(R) \\
2766 \\
3486(R) \\
3416 \\
4119(R) \\
4167 \\
4033 \\
4983(R) \\
5283 \\
4918 \\
5283(R) \\
5233 \\
5744(R) \\
5619 \\
6579(R) \\
6742 \\
6477 \\
6742(R) \\
6604(R) \\
7562(R) \\
7496 \\
8344(R) \\
8370 \\
8251 \\
9084(R) \\
8903 \\
9785(R) \\
9830 \\
9706 \\
10600(R) \\
10451 \\
11321(R) \\
11380 \\
\end{array}$ & $\begin{array}{l}\text { ACTCAGATCTGGGAGGCAATTA } \\
\text { TCTTTAGTCACTTTAGGTGGCC } \\
\text { GATGTTGATACCACCTACCAG } \\
\text { GTAGAATATTACAACCGGCCC } \\
\text { CCTGTTCCATCAGCTTAC } \\
\text { TGTAAAACGACGGCCAGTATGGATTTGACAGCCC } \\
\text { GGCACTGTTCTTCAGTAAGACG } \\
\text { AGGTATTGGGAGATCGATGG } \\
\text { CTCTTGAGCATGCTTTACCAG } \\
\text { GATAGCCGGTTGACTTCATC } \\
\text { CAGCCATCACTAACACAGAC } \\
\text { GATAGCCGGTTGACTTCATC } \\
\text { TGAAATCCAACCCACCACC } \\
\text { AGTCTGCACTGTTTCAGCTGC } \\
\text { TTTCTGAAGGAGGATGGCC } \\
\text { TCAGAGTTTCCTCAGCTCCG } \\
\text { GGGTTATCCTCTGATTTCG } \\
\text { GGAGAAAGCAAACAAGTGGC } \\
\text { ATATCTGTAGCTGCCAGCC } \\
\text { GTGATGTGGTCCACATTCTGG } \\
\text { GAAATTGTCCGTAAGATGCG } \\
\text { GTGATGTGGTCCACATTCTGG } \\
\text { GGAATACCAGAAACACATGG } \\
\text { CCTCTCTCTTTCTCTCATCTG } \\
\text { GGGTGAATCTGAAAGAGGAAG } \\
\text { TCAGCTTCTGTTAGCCACTG } \\
\text { GGCATCTGTTTTGGGGATGC } \\
\text { AAATGTACAAGGACCGACAAGG } \\
\text { GGCATCTGTTTTTGAGGATTGC } \\
\text { TCCTGAGATTGGGAACATGCT } \\
\text { TAGTAACCACAGGTTGTGTCAC } \\
\text { GGACTGACCACTATTGGAG } \\
\text { GGCAGTTGTTTCAGCTTCTGTA } \\
\text { TTACGGGTAGCATCCTGTAGGA } \\
\text { GGCTGCTTTGGAAGAAACTC } \\
\text { GATCCCTTGATCACCTCAGCTTGG } \\
\text { AATGTCACTCGGCTTCTACGAAA } \\
\text { TCCCTGTTCGTCCCGTATC } \\
\text { TACACAGGGAATGATGCCAG } \\
\text { CAATTTGGTCAACGTCCCTC } \\
\text { GCTCTCATTAGGAGAGATGC } \\
\text { TTCTGGCCAGTAGATTCTGC } \\
\text { GATACTAAGGACTCCATCGC } \\
\text { CATGCGGGAATCAGGAGTTG }\end{array}$ & $\begin{array}{l}\text { 'Odd' } \\
\text { 'Even' }\end{array}$ & $\begin{array}{l}3 \\
4 \\
\\
4 \\
5\end{array}$ & $\begin{array}{l}1 \cdot 1 \\
1 \cdot 1 \\
1 \cdot 2 \\
1 \cdot 2 \\
\\
2 \cdot 1 \\
2 \cdot 1 \\
2 \cdot 2 \\
2 \cdot 2 \\
3 \cdot 1 \\
3 \cdot 1 \\
3 \cdot 1 \\
3 \cdot 2 \\
3 \cdot 2 \\
3 \cdot 3 \\
3 \cdot 3 \\
4 \cdot 1 \\
4 \cdot 1 \\
4.1 \\
5 \cdot 1 \\
5 \cdot 1 \\
5 \cdot 2 \\
5 \cdot 2 \\
5 \cdot 3 \\
5 \cdot 3 \\
6 \cdot 1 \\
6 \cdot 1 \\
6 \cdot 2 \\
6 \cdot 2 \\
6 \cdot 3 \\
6 \cdot 3 \\
7 \cdot 1 \\
7 \cdot 1 \\
7 \cdot 2 \\
7 \cdot 2 \\
8 \cdot 1 \\
8 \cdot 1 \\
8 \cdot 2 \\
8 \cdot 2\end{array}$ \\
\hline
\end{tabular}




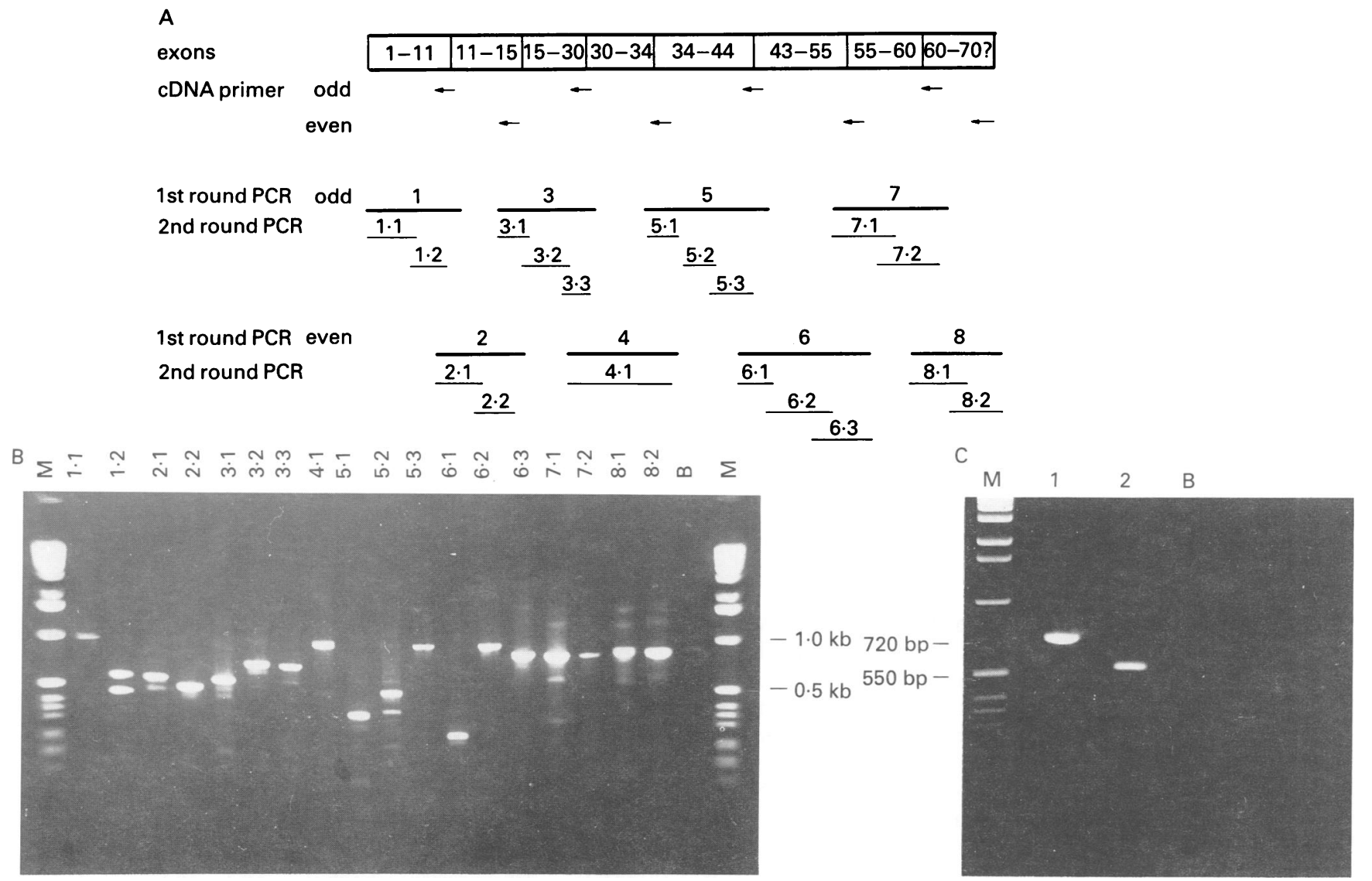

Figure 1 Two stage cDNA amplification of the DMD gene transcript using peripheral blood lymphocyte RNA. (A) Diagram of reverse transcription and amplification strategy. (B) The 18 overlapping fragments of a healthy control after second round PCR and electrophoresis. $B$ blank (no RNA included), $M$ size standard (1 kb ladder, BRL, USA). The doublet band in lane $1 \cdot 2$ is the result of skipping of exon 9 as already observed by Roberts et al.'9 This was confirmed by DNA sequencing (data not shown). (C) Aberrant fragment $3 \cdot 2$ (see $A$ ). Lane 1 healthy control, lane 2 DMD patient.

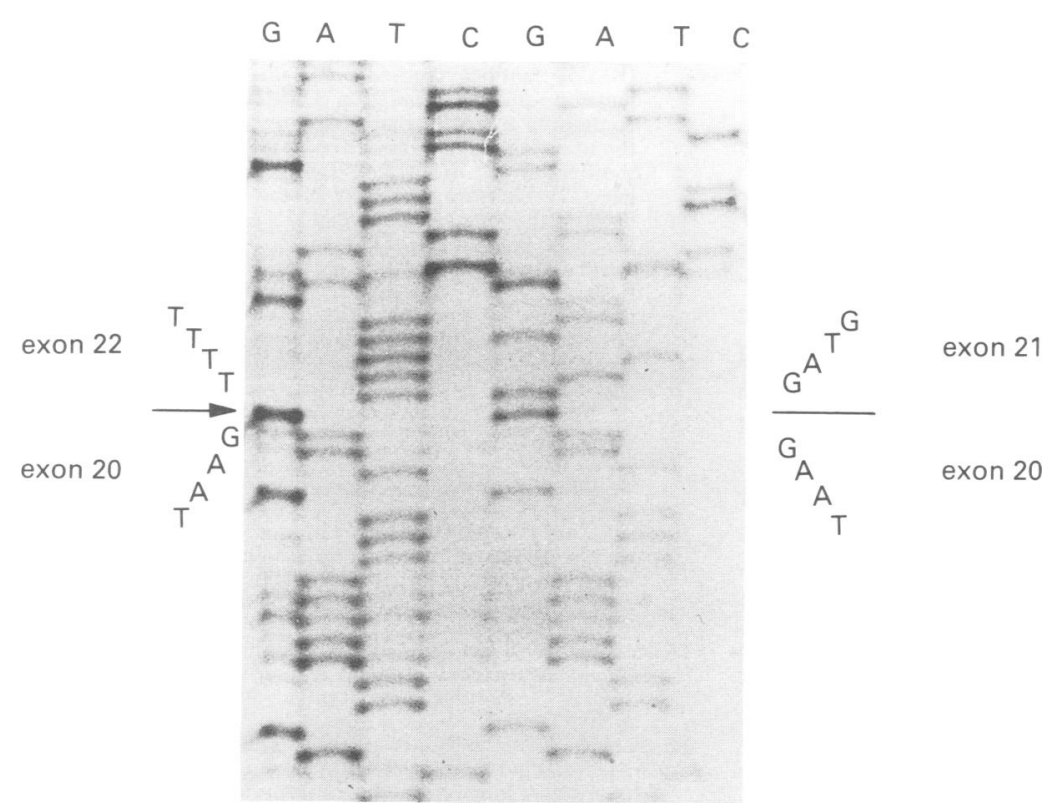

Figure 2 Autoradiograph of direct DNA sequence analysis of fragment 3.2. The patient's cDNA (left) shows direct joining of exons 20 and 22 (arrow) as compared to the exon 20 to 21 junction in a healthy control (right). specific amplification was performed on genomic DNA (fig 3). This indicated the absence of exon 21 in the patient's genomic DNA. Another 11 DMD patients without an apparent deletion in 'multiplex' amplifications were tested simultaneously, but no other deletion of exon 21 was detected.

\section{Discussion}

The limited detection rate of DMD gene mutations does not only complicate family studies, but also drastically diminishes the value of negative results in differential diagnosis. Nevertheless, the screening for deletions alone is extremely laborious and time consuming, since either multiple hybridisations or numerous genomic DNA amplifications have to be performed. The latter concentrate on the two deletion 'hot spots' at the 5 ' end and in the middle of the DMD gene. Furthermore, not all exon boundaries are known.

We have previously shown the diagnostic utility of ectopic lymphocyte RNA by the characterisation of a new point mutation in the F8 gene causing haemophilia $A,{ }^{23}$ and the detection of pathological DMD gene transcripts in a female muscular dystrophy carrier. ${ }^{18}$ Here we show that the DMD gene transcript, which is distributed over approximately $0 \cdot 1 \%$ of the human genome, can be 


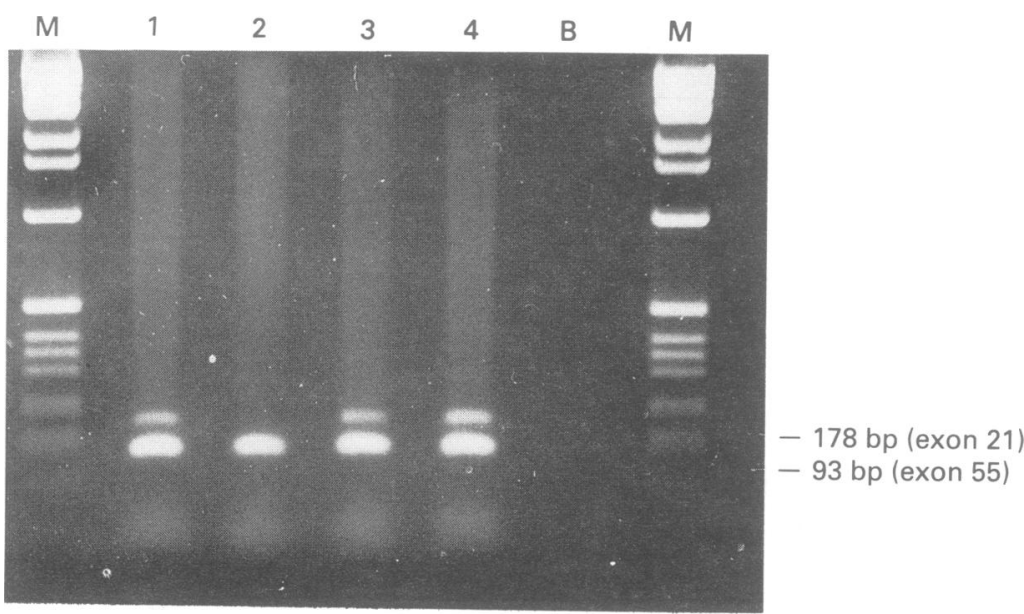

Figure 3 Genomic amplification of exon 21 and 55 (internal control). Lanes 1, 3, 4 healthy controls; lane 2 DMD patient; $B$ blank (no genomic DNA), $M$ size marker (1 kb ladder, $B R L, U S A$ ).
Thus, all kinds of mutations might be detectable in a single comprehensive procedure using readily accessible lymphocyte RNA. An increased detection rate for DMD mutations would also be a major advantage for differential diagnosis. However, the above procedures are in no way limited to the DMD gene. Slomski et $a l^{30}$ have stressed the ubiquitous nature of ectopic transcripts by the rather extreme example of characterising transcripts of spermatid specific genes in lymphocytes of adult non-pregnant females. As peripheral blood can substitute for specifically expressing tissue, ectopic RNA studies are also suitable for rapid carrier detection in female relatives of DMD patients carrying a deletion. Since the family of our patient currently lives abroad, no such analysis was performed here. Such applications, however, have already been described elsewhere. ${ }^{1931}$

\section{Note added in proof}

Since submission of this paper, we have identified a genomic deletion of exon 18 in another patient by the same means. lapping fragments. By these means we identified a deletion of exon 21 in the cDNA of a DMD patient, who exhibited no mutation in standard multiplex DNA amplification.

Analysis of the genomic DNA indicated that the 'skipping' of exon 21 resulted from a chromosomal deletion and direct sequence analysis confirmed that exon 20 was precisely spliced to exon 22 . This juxtaposition results in a reading frame shift, which in the majority of cases causes the severe Duchenne phenotype according to the hypothesis of Monaco et al. ${ }^{24}$ Here, an in frame termination signal (TGA) is created 14 codons downstream in exon 22. Chelly et $a l^{25}$ showed that ectopic lymphocyte DMD transcripts reflect the mRNA structure found in expressing tissue and we have confirmed this observation for transcripts of the cystic fibrosis transmembrane conductance regulator (CFTR) gene. ${ }^{26}$ According to these findings, a dystrophin protein truncated after exon 20 can be expected in our DMD patient. This is in agreement with the absence of detectable dystrophin in immunohistochemical analysis and confirms the diagnosis of a severe Duchenne type muscular dystrophy.

To our knowledge, a deletion of exon 21 alone has not been reported so far. The detection of such small deletions outside the deletional hot spots of the DMD gene at the genomic level would be extremely laborious. Following the above strategy, abnormal splicing patterns owing to mutated junction sequences ${ }^{27}$ might be as readily detectable as the described deletion. Furthermore, the number and size of our second round PCR products renders them suitable substrates for point mutation screening. A number of different scanning procedures are at hand for this purpose. Plieth et al ${ }^{8}$ have recently shown that the rapid single strand conformation polymorphism (SSCP) analysis detected all five CFTR mutations tested in a retrospective study. Roberts et $a l^{29}$ recently reported seven point mutations in the dystrophin gene identified by chemical mismatch detection.
The authors wish to thank David N Cooper for helpful comments on the manuscript, Doris Grosse for technical assistance, and Doris Immke for secretarial assistance. Our laboratory is supported by the Deutsche Forschungsgemeinschaft and the Deutsche Gesellschaft zur Bekämpfung der Muskelkrankheiten.

1 Emery AEH. Population frequencies of inherited neuromuscular diseases - a world survey. Neuromusc Dis 1991;1:19-29.

2 Koenig M, Hoffman EP, Bertelson CJ, Monaco AP, Feener C, Kunkel LM. Complete cloning of the Duchenne muscular dystrophy (DMD) cDNA and preliminary muscular dystrophy (DMD) CDNA and preliminary
genomic organization of the DMD gene in normal and genomic organization of the DMD gene
affected individuals. Cell 1987;50:509-17.

3 Koenig M, Monaco AP, Kunkel LM. The complete sequence of dystrophin predicts a rod-shaped cytoskeletal quence of dystrophin predict
protein. Cell $1988 ; 53: 219-28$.

4 Den Dunnen JT, Grootscholten PM, Bakker E, et al. (DMD) gene: FIGE and CDNA analysis of 194 cases reveals 115 deletions and 13 duplications. Am f Hum Genet 1989;45:835-47.

5 Darras BT, Blattner P, Harper JF, Spiro AJ, Alter S, Francke U. Intragenic deletions in 21 Duchenne muscular dystrophy (DMD)/Becker muscular dystrophy (BMD) families studied with the dystrophin cDNA: location of breakpoints on HindIII and BgIII exoncontaining fragment maps, meiotic and mitotic origin of the mutations. Am $\mathcal{f}$ Hum Genet 1988;43:620-9. key CT. Deletion screening of the Duchenne muscular dystrophy locus via multiplex DNA amplification. Nucleic Acids Res 1988;16:11141-56.

7 Chamberlain JS, Gibbs RA, Ranier JE, Caskey CT. Multiplex PCR for the diagnosis of Duchenne muscular tystrophy. In: Innis M, Gelfand D, Sninski J, White T, dystrophy. In: Innis $\mathrm{M}$, Gelfand $\mathrm{D}$, Sninski J, White $\mathrm{T}$, San Diego: Academic Press, 1990;272-81.

8 Beggs AH, Koenig M, Boyce FM, Kunkel LM. Detection of $98 \%$ of $D M D / B M D$ gene deletions by polymerase

9 Lindlöf M, Kiuru A, Kääriäinen H, et al. Gene deletions in $\mathrm{X}$-linked muscular dystrophy. Am $\mathcal{f}$ Hum Genet 1989;44:496-503.

10 Hu X, Ray PN, Murphy EG, Thompson MW, Worton RG. Duplicational mutation at the Duchenne muscular dystrophy locus: its frequency, distribution, origin, and phenotype/genotype correlation. Am $\mathcal{f}$ Hum Genet 1989;46:682-95. Rapid carrier and prenatal diagnosis of Duchenne and Becker muscular dystrophy. Nucleic Acids Res 1990;17:811.

12 Abbs S, Roberts RG, Mathew CG, Bentley DR, Bobrow $M$. Accurate assessment of intragenic recombination frequence within the Duchenne muscular dystrophy gene. Genomics 1990;7:602-6.

13 Russo A, Barbujani G, Mostacciuolo ML, et al. Sporadic cases in Duchenne muscular dystrophy. Hum Genet 1987;76:230-5. Topography of the Duchenne muscular dystrophy

6 Chamberlain JS, Gibbs RA, Ranier JE, Nguyen PN, Cas-

11 Roberts RG, Cole CG, Hart KA, Bobrow M, Bentley DR. 
14 Richards RI, Friend K. Determination of Duchenne muscular dystrophy carrier status by single strand conformation polymorphism analysis of deleted regions of the dystrophin locus. $\mathcal{F}$ Med Genet 1991;28:856-9.

15 Bulman DE, Gangopadhyay SB, Bebchuck KG, Worton RG, Ray PN. Point mutation in the human dystrophin gene: identification through western blot analysis. Gemomics 1991;10:457-60

16 Chelly J, Concordet JP, Kaplan JC, Kahn A. Illegitimate transcription: transcription of any gene in any cell type. transcription: transcription of any gene in

17 Sarker G, Sommer SS. Access to a messenger RNA sequence or its protein product is not limited by tissue or species specificity. Science 1989;244:331-4.

18 Schloesser M, Slomski R, Wagner M, et al. Characterization of pathological dystrophin transcripts from the lymphocytes of a muscular dystrophy carrier. Mol Biol Med 1990;7:519-23

19 Roberts RG, Bentley DR, Barby TF, Manners E, Bobrow $M$. Direct diagnosis of carriers of Duchenne and Becker muscular dystrophy by amplification of lymphocyte RNA. Lancet 1990;336:1523-6.

20 Roberts RG, Barby TFM, Manners E, Bobrow M, Bentley DR. Direct detection of dystrophin gene rearrangements by analysis of dystrophin mRNA in peripheral blood lymphocytes. Am f Hum Genet 1991;49:298-310.

21 Zielenski J, Rozmahel R, Bozon D, et al. Genomic DNA sequence of the cystic fibrosis transmembrane conductance regulator (CFTR) gene Genomics 1991;10.214-28.

22 Miller SA Dykes DD, Polesky HF. A simple salting out procedure for extracting DNA from human nucleated procedure for extracting DNA from
cells. Nucleic Acids Res 1988;16:1215.

23 Berg LP, Wieland K, Miller DS, et al. Detection of a novel point mutation causing haemophilia A by PCR/direct sequencing of ectopically-transcribed factor VIII mRNA Hum Genet 1990;85:655-8.

24 Monaco AP, Bertelson CJ, Liechti-Gallati S, Moser H, Kunkel LM. An explanation for the phenotypic differences between patients bearing partial deletions of the DMD locus. Genomics 1988;2:90-5.

25 Chelly J, Gilgenkrantz H, Hugnot JP, et al. Illegitimate transcription. Application to the analysis of truncated transcription. Application to the analysis of truncated
transcripts of the dystrophin gene in nonmuscle cultured cells from Duchenne and Becker patients. $f$ Clin Invest cells from Duch

26 Slomski R, Schloesser M, Berg LP, et al. Omission of exon 12 in CFTR gene transcripts. Hum Genet (in press)

27 Krawczak M, Reiss J, Cooper DN. The mutational spectrum of single base-pair substitutions in mRNA splice unctions of human genes: causes and consequences. Hum Genet (in press).

28 Plieth J, Rininsland F, Schlösser M, Cooper DN, Reiss J. Single-strand conformation polymorphism (SSCP) analysis of exon 11 of the CFTR gene reliably detects more than one third of non- $\triangle F 508$ mutations in German more than one third of non- $\triangle \mathrm{F} 508$ mutations in Gern

29 Roberts RG, Bobrow M, Bentley DR. Point mutations in the dystrophin gene. Proc Natl Acad Sci USA 1992;89:2331-5.

30 Slomski R, Schloesser M, Chlebowska H, Reiss J, Engel W. Detection of human spermatid-specific transcripts in the lymphocytes of males and females. Hum Genet 1991;87:307-10.

31 Niemann-Seyde S, Slomski R, Rininsland F, Ellermeyer U, Kwiatkowska T, Reiss J. Molecular genetic analysis of 67 patients with Duchenne/Becker muscular dystrophy. Hum Genet (in press). 